\title{
AN EMPIRICAL INVESTIGATION OF E-BANKING IN THE KURDISTAN REGION OF IRAQ: THE MODERATING EFFECT OF ATTITUDE
}

\author{
YADGAR TAHA M. HAMAKHAN ${ }^{1}$
}

Abstract

\begin{abstract}
The banking industry is one of the most important industries in developing countries, thus it plays a major role in the financial industry. Moreover, e-banking has simplified financial transactions. This study investigates the effect of individual factors on user behaviour and the moderating effect of attitude on the relationship between individual factors and user behaviour based on the Unified Theory of Acceptance and Use of Technology. A model suggests a second-order components research framework that improves current explanations of electronic banking channel services acceptance and sheds light on the role of attitude on the acceptance of electronic banking channel services which is the most important key concern. Data were collected using an online questionnaire with 476 valid responses from academic staff who work at the University of Sulaimani; the model has been tested using the Partial Least Squares-Structural Equation Modeling approach. The results show that individual factors have a positive effect on user behaviour and also show that attitude has a negative effect on the relationship between individual factors and user behaviour as a moderator.
\end{abstract}




\section{INTRODUCTION}

The banking industry is one of the most important industries in developing countries, thus it playsa major role in the financial industry, growth economics and sustainable development, particularly in the case of Electronic Banking service in the Kurdistan Region of Iraq (KRI), in order to move the society from cash and shift it to electronic "paperless" transactions which are more reliable and convenient besides which can be seen in developed countries and government policy should support this system by providing E-government service (Baabdullah et al., 2019; Torres et al., 2017; Marakarkandy et al., 2017).The two factors of Information Technology (IT) and Information Communications Technology (ICT) can affect E-banking service rapidly (Wang et al., 2017) which is still run in traditional ways in the KRI (Riffai et al., 2011).

With regards to the term of E-banking based on the literature review, Electronic Banking services can be defined as a new kind of reform in banking industry services, thus it has changed massively the electronic business and government environments in very recent decades (Sohail \& Shanmugham, 2002; Huang et al., 2011; Hoehle et al., 2012; M. Hama Khan, 2019; Khan, 2018).

According to Fishbein and Ajzen (1975) attitude is defined as the individual's feelings about performing a behaviour and the authors considered that behavioural intentions are a function of an individual's attitude toward the behaviour and subjective norms surrounding the performance of the behaviour, an individual's (accept, agree, like) or (reject, refuse, dislike) feelings about new Information and Communication Technology (ICT) (Wang et al., 2017).

The purpose of this study is to investigate a nominated second-order components research model, based on a systematic relevant literature review from the author's PhD thesis (160 articles) and highlights the role of attitude on the acceptance of Electronic Banking services. Further, attitude is used as a moderator in the relationship between individual factors and user behaviour based on the Unified Theory of Acceptance and Use of Technology.

\section{LITERATURE REVIEW AND RESEARCH HYPOTHESIS}

E-banking has simplified financial transactions through different technological platforms, whether it is an automated teller machine (ATM), computer, mobile phone or tablet in order to access information on a customer's account via electronic service (online service) (Harris et al., 2016; Butt \& Aftab, 2013), instead of a visit to a brickand-mortar banking branch (offline service) (Daniel, 1999; Lee \& Lee, 2000).The necessity of E-Banking services with the new generation's lifestyle today is reached by different levels of technology innovations (Khan, 2018; Chawla \& Joshi, 2017; Aljanabi \& Dileep, 2012; Rahomee et al., 2014; Aljanabi \& nor azila, 2015a, 2015b; Alkhaffaf \& Abdulqadir, 2016; Mohd Noor \& Abdulqadir, 2016; Aljanabi \& Dileep, 2013).E-banking provides self-service technologies in an electronic environment (Shih \& Fang, 2004; Hoehle et al., 2016).Moreover, it is quite obvious that an E-banking system goes up against the traditional banking system (offline banking) (Floh \& Treiblmaier, 2006; Kingshott et al., 2018) for many reasons, such as cost (Luarn \& Lin, 2004; Abrahão et al., 2016), time (Hanafizadeh \& Khedmatgozar, 2012), knowledge of IT (Mallat et al., 2009; Luo et al., 2010) geographic expanse, pollution, traffic jams, parking problems, saving trees (paperless transactions), for better management (Claro \&Rosa, 2016), attracting more customers (Mann \& Sahni, 2012) through different communication channels such as social media, mass media (Tran \& Corner, 2016), e-service (Al-Qeisi \& Hegazy, 2015) and financial performance of community banks (Acharya et al., 2008).

Nowadays Hawala plays a major part in the financial market place in the $\mathrm{KRI}$ and affects the banking sector (Passas, 2005a, 2005b), even in the future because it is not just a habit, it has become a trusted and easy way for people. Hawala is a local traditional transaction system (Schramm \& Taube, 2003) for money transfer between the $\mathrm{KRI}$ and other countries, no matter whether for business or for other purposes based on using the Jordan, Iran or United Arab Emirates banking sectors. Most of the foreign exchangers offices use Hawala instead of using the KRG banking sector (Bunt, 2008; Liargovas \& Repousis, 2011). The Hawala system is cheaper, faster and more trustworthy compared to the banking system in the KRI because of past performance of the KRI banking system (Faith, 2011; Ismail, 2007). Besides that, people have had a good experience with the Hawala system in the past which is 
why people trust Hawala more than the banking system. Unfortunately, no official statistics exist regarding the level of Hawala activity, but according to a USAID report (2008) Hawala transactions account for substantially more than half the currency in circulation held outside the banking sector. Anecdotal evidence suggests that the volume of Hawala transactions easily exceeds the equivalent of US $\$ 3$ billion annually just in the KRI.

According to the USA embassy website in Iraq and their report on Hawala, there are 2,000 financial institutions that use Hawala and exchange their currency via their Hawala system. The problem is that Hawala is used in the region for both legitimate and illegitimate reasons, also there are no investigations or fines there, which means there is no fully financial monetary system to prohibit illegitimate situations because many of Hawaladars became licensed from the government. That is why there is financial chaos in the region, commonly known as financial corruption (Soudj in, 2015). Money laundering is an important problem in the region even in Iraq generally as it is linked to the Hawala system (Shanmugam, 2004; Goede, 2003; Schneider, 2010; Veul et al., 2016).

Venkatesh et al., (2003) presented the Unified Theory of Acceptance and Use of Technology UTAUT as the integration of eight different models of acceptance and use of technology. UTAUT is a definitive model that synthesizes what is known and provides a foundation to guide future research in this area (Venkatesh et al., 2003). With regards to the theoretical perspective, UTAUT can be a good foundation for this study (Abu Shanab \& Pearson, 2007), in order to test the intention to accept E-banking service (Tan \& Lau, 2016; Alalwan et al.,2018), UTAUT provided a refined view of how the determinants of intention and behaviour evolve over time (Venkatesh et al., 2003).

In short, UTAUT is another extension of the TAM that integrates constructs, including (performance expectancy, effort expectancy, and facilitating conditions).

Performance Expectancy is defined as the degree to which an individual believes that using the system will help him/her to attain gain in job performance (Venkatesh et al., 2003; Zhang et al., 2018). In contrast, Yaseen and El Qirem (2018) found that Performance expectancy and hedonic motivation are not significant predictors.

Effort Expectancy is defined as the degree of ease associated with the use of the system (Venkatesh et al., 2003; Warsame \& Ireri, 2018; Wang et al., 2017).

Social Influence is defined as the degree to which an individual perceives the importance of the beliefs of others on whether he or she should use the new system (Venkateshet al., 2003; Yaseen \& El Qirem, 2018).

Facilitating Conditions are defined as the degree to which an individual believes that an organisational and technical infrastructure exists to support the use of the system (Venkatesh et al., 2003).In contrast, Al-Qeisi and Hegazy (2015) found that facilitating conditions were not strong determinants of usage behaviour.

Individual level technology adoption is one of the most mature streams of IS research (Venkatesh et al., 2007) thus in this research Individual Factors are rated as Second-order (higher-order components) contained from four sub-dimensional indicators (lower-order components) which are performance expectancy, effort expectancy, and facilitating conditions. With regard to the UTAUT 1 and 2 (Venkatesh et al., 2012).Table 1 presents a summary of the main findings of selected empirical studies based on UTAUT.

\section{Table 1: Summary of the main findings of selected empirical studies based on UTAUT}

\begin{tabular}{|c|c|c|c|}
\hline Authors \& year & Finding & Sample & Country \\
\hline Baabdullah et al. (2019) & $\begin{array}{l}\text { The main factors - performance expectancy, price } \\
\text { value, facilitating conditions, hedonic motivation, } \\
\text { habit, system quality and service quality - were } \\
\text { found to have a significant impact on actual user } \\
\text { behaviour. }\end{array}$ & 320 Customers & Saudi Arabia \\
\hline Farah et al. (2018) & $\begin{array}{l}\text { Most of the predictors of intention, including } \\
\text { perceived value, performance expectancy, habit, } \\
\text { social influence, effort expectancy, hedonic } \\
\text { motivation (except for facilitating condition, } \\
\text { perceived risk and trust), are significant. All } \\
\text { predictors of user behaviour are significant. }\end{array}$ & 490 respondents & Pakistan \\
\hline
\end{tabular}




\begin{tabular}{|c|c|c|c|}
\hline Alalwan et al. (2018) & $\begin{array}{l}\text { Behavioural intention is significantly influenced by } \\
\text { performance expectancy, effort expectancy, hedonic } \\
\text { motivation, price value and perceived risk; however, } \\
\text { social influence does not have a significant impact } \\
\text { on behavioural intention. }\end{array}$ & 348 Customers & Jordan \\
\hline Alalwan et al. (2017) & $\begin{array}{l}\text { Behavioural intention is significantly and positively } \\
\text { influenced by performance expectancy, effort expectancy, } \\
\text { hedonic motivation, price value and trust. }\end{array}$ & 343 participants & Jordan \\
\hline Maruping et al. (2017) & $\begin{array}{l}\text { Found two determinants of behavioural expectation and } \\
\text { theorize how these determinants influence BE in concert } \\
\text { with four key moderators from UTAUT. }\end{array}$ & 321 users of a new IT. & USA \\
\hline Torres et al. (2017) & $\begin{array}{l}\text { Performance expectancy and effort expectancy had } \\
\text { a positive impact on the use of financial websites in } \\
\text { Colombia, while government support did not have a } \\
\text { significant impact. }\end{array}$ & 600 participants & Colombia \\
\hline Abrahão et al. (2016) & $\begin{array}{l}\text { A guide to participants in the payments market to develop } \\
\text { a service for mobile payments with good performance, } \\
\text { ease to use, security and promoting the action of the social } \\
\text { circle of the individual at a fair price, in other words, that } \\
\text { meets needs and expectations of today's mobile phone } \\
\text { users. }\end{array}$ & 605 respondents & Brazil \\
\hline Bhatiasevi (2016) & $\begin{array}{l}\text { Performance expectancy, effort expectancy, social } \\
\text { influence, perceived credibility, perceived convenience, } \\
\text { and behavioural intention to use mobile banking posited } \\
\text { a positive relationship. Contrary to previous studies, } \\
\text { the hypotheses tested perceived that financial cost and } \\
\text { facilitation conditions in the adoption of mobile banking } \\
\text { were not supported. }\end{array}$ & 272 Customers & Thailand \\
\hline $\begin{array}{l}\text { Baptista and Oliveira } \\
\text { (2015) }\end{array}$ & $\begin{array}{l}\text { Performance expectancy, hedonic motivation, and habit } \\
\text { were found to be the most significant antecedents of } \\
\text { behaviour intention. To explain the mobile banking use } \\
\text { behaviour the habit and culture moderator effects on } \\
\text { behaviour intention over user behaviour were the most } \\
\text { important drivers. }\end{array}$ & 252 Users & Mozambique \\
\hline Al-Qeisi et al. (2014) & $\begin{array}{l}\text { The technical, general content and appearance dimensions } \\
\text { of a website are most important for users. These dimensions } \\
\text { are significantly related to userbehaviour directly and } \\
\text { indirectly. }\end{array}$ & 216 users & UK \\
\hline
\end{tabular}

\section{Source: Own elaboration}

From the above discussion, the researcher hypothesised as:

H1. Individual Factors have a positive effect on User Behaviour.

\section{MODERATING EFFECT OF ATTITUDE}

According to the (TAM), attitude is a function of perceived ease of use and perceived usefulness (Davis, 1989; Davis et al., 1989). In other words, attitude can be an outcome of positive or negative feeling towards using a new system or technology such as E-banking service (Karjaluoto et al., 2002; Davis, 1989). Davis (1989) found that attitude plays a critical role in the intention to use a new technology. Also, Davis (1989) described attitude as a degree of evaluative effect that an individual associates with using the target system. Attitude toward using technology is defined as an individual's overall affective reaction to using a system (Venkatesh et al., 2003).There are numerous factors beyond accepting this system safely and effectively. Attitude could be the most significant factor in achieving success for bankers (M. Hama Khan, 2019; Khan,2018). Customers are always free and right to accept what they want whether they are in the KRI or somewhere else based on their attitude (Cheng et al., 2006; Muñoz-Leiva et al., 2017). Fen Lin (2011) found that the relationship between perceived competence and attitude is greater for potential customers than for repeat customers.

With regards to the factors, a group of factors can effect an individual's attitudes to intend to accept an E-banking system such as self-service technologies, attitude can effect social pressures on intention to accept 
E-banking service (Chaouali \& El Hedhli, 2019; Chauhan et al., 2019) saw demographic characteristics (Chawla \& Joshi, 2017, 2018), subjective norm (Ting et al., 2016), word of mouth impact (Mehrad \& Mohammadi, 2016), electronic service (Ayo et al., 2016),etc.

With regards to the theories, attitude has been employed in three main theories related to consumer behaviour, namely (Theory of Reasoned Action (TRA) by Fishbein and Ajzen (1975),(Theory of Planned Behaviour
(TPB) by Ajzen (1991) and (Technology Acceptance Model (TAM) (Davis, 1989, Davis et al., 1989). From these theories and literature review, this researcher understood that attitude was not used as a moderator, that is why the researcher has decided to use attitude as a moderator in this research (Khan, 2018; M. Hama Khan, 2019).Table 2 presents a summary of the main findings of selected empirical studies related to attitude.

\section{Table 2: Summary of the main findings of selected empirical studies related to Attitude}

\begin{tabular}{|c|c|c|c|}
\hline Authors \& year & Finding & Sample & Country \\
\hline $\begin{array}{l}\text { Chaouali and El Hedhli } \\
\text { (2019) }\end{array}$ & $\begin{array}{l}\text { Attitudes toward automated teller machines (ATMs) } \\
\text { and online banking significantly predict attitude to- } \\
\text { ward mobile banking. }\end{array}$ & 1250 clients & France \\
\hline Giovanis et al. (2019) & $\begin{array}{l}\text { Perceived risk negatively affects attitude formation } \\
\text { and inhibits willingness to use MB services. }\end{array}$ & 931 potential users & Greece \\
\hline Chauhan et al. (2019) & $\begin{array}{l}\text { The significant positive influence of perceived useful- } \\
\text { ness, ease of use, attitude on consumer's intention to } \\
\text { adopt internet banking. }\end{array}$ & 487 consumers & India \\
\hline Geo et al. (2017) & $\begin{array}{l}\text { The results showed the positive effect of perceived } \\
\text { behavioural control (PBC) and attitudes (ATT) toward } \\
\text { m-banking adoption intentions. }\end{array}$ & 189 Customers & Pakistan \\
\hline $\begin{array}{l}\text { Chawla and Joshi } \\
\text { (2017) }\end{array}$ & $\begin{array}{l}\text { Perceived trust, perceived ease of use (PEOU), perce- } \\
\text { ived lifestyle compatibility, perceived efficiency and } \\
\text { perceived convenience significantly impacted user } \\
\text { attitude. However, user attitude was not found to dif- } \\
\text { fer significantly between demographic variables. }\end{array}$ & 367 Users & India \\
\hline $\begin{array}{l}\text { F. Mu noz-Leiva et al. } \\
\text { (2017) }\end{array}$ & $\begin{array}{l}\text { The results obtained in this study demonstrate how } \\
\text { attitude determines mainly the intended use of mo- } \\
\text { bile apps, discarding usefulness and risk as factors } \\
\text { that directly improve its use. }\end{array}$ & 103 regular users & Spain \\
\hline Ting et al. (2016) & $\begin{array}{l}\text { The findings showed that attitude, subjective norms } \\
\text { and perceived behavioural control are positively pre- } \\
\text { dicted by their respective belief factors }\end{array}$ & 311 Users & Malaysia \\
\hline $\begin{array}{l}\text { Mehrad and Moham- } \\
\text { madi (2016) }\end{array}$ & $\begin{array}{l}\text { The results revealed that "Word of Mouth" was fo- } \\
\text { und to be the main factor affecting users attitudes } \\
\text { toward the use of mobile banking. }\end{array}$ & 384 Users & Iran \\
\hline $\begin{array}{l}\text { Mansour, Eljelly and } \\
\text { Abdullah (2016) }\end{array}$ & $\begin{array}{l}\text { The study found that the customers' attitude toward } \\
\text { various bank technologies is not the same and is in- } \\
\text { fluenced by different factors. The results revealed } \\
\text { that bank customers who are users of ATMs are in- } \\
\text { fluenced by its convenience, ease of use and service } \\
\text { quality, whereas credibility was not seen as a signifi- } \\
\text { cant driver. Mobile users were found to be influen- } \\
\text { ced more by the benefits and ease of use and service } \\
\text { quality, whereas internet customers were influenced } \\
\text { by the benefits and ease of use and credibility of the } \\
\text { systems. }\end{array}$ & 132 Customers & Sudan \\
\hline Butt and Aftab (2013) & $\begin{array}{l}\text { The results of this research suggested that attitude } \\
\text { towards Halal banking positively influences perce- } \\
\text { ived e-service quality and overall e-satisfaction with } \\
\text { the online services of Islamic banks. }\end{array}$ & 292 Users & Pakistan \\
\hline
\end{tabular}

Source: Own elaboration 
From the above discussion, the researcher hypothesised the moderating effect as:

H1a. Attitude will moderate the relationship between Individual Factors and User Behaviour.

\section{RESEARCH MODEL AND HYPOTHESIS}

In this research, the framework is extended from TAM \& UTAUT. Moreover, the research model uses the three latent variables (Individual Factors as an independent variable, Attitude as a moderator and User Behaviour as dependent variable) because it has higher-order constructs and reflective-formative types. The secondorder components (Individual Factors) is based on four subdimensions (lower-order components) which are performance expectancy, effort expectancy, and facilitating conditions. Individual Factors are more concentrated when it is second-order and conceptually is more reliable, besides second-order components reduce the number of paths in the model in which there is only one path from the Independent Variable to the Dependent Variable (Sarstedt et al., 2019). To empirically test the model, the researcher applied a partial least square structural equation modeling (PLS-SEM) approach by SmartPLS (V. 3.2.8) (Aljanabi, 2017; Aljanabi et al., 2018, 2019). Figure 1 shows the framework.

\section{RESEARCH METHOD}

\section{Data Collection and Sample Selection}

The data sample collected from academic staff at the University of Sulaimani which is located in Sulaimani city in the KRI was done via electronic questionnaires in the local language, in order to make it more clear for the participants, which are the (Kurdish\Sorani). The data have been collected on Google Forms (Alaarj et al., $2017 a, 2017 b)$. The length of time given to respondents to complete this survey was 2 months. A total of 476 usable questionnaires were collected, since the questionnaires were electronic, there was no incomplete questionnaire.

\section{RESULTS AND DISCUSSION}

According to Hair et al., (2017) the model should test through two stages which are the measurement model and the structural model (Henseler et al., 2009). It is also necessary to extend a (repeated) indicators approach to analyse the higher-order constructs' measurement models and the structural model since the sample size is sufficiently large (Sarstedt et al., 2019). In this research the hypothesis was tested by using the one-tailed test instead of the two-tailed test, in order to minimize the type II error (Latan et al., 2016).The Demographic Information were

Table 3: Demographic Information

\begin{tabular}{|c|c|c|c|c|}
\hline \multicolumn{2}{|c|}{ 1. Age } & Value & Count & Percent \\
\hline \multirow{2}{*}{$\mathbf{N}$} & Valid & 476 & & \\
\hline & Missing & 0 & & \\
\hline \multirow{3}{*}{ Labelled Values } & 1 & $18-40$ & 366 & $76.9 \%$ \\
\hline & 2 & $41-60$ & 104 & $21.8 \%$ \\
\hline & 3 & $61-80$ & 6 & $1.3 \%$ \\
\hline \multicolumn{2}{|c|}{ 2. Gender } & Value & Count & Percent \\
\hline \multirow{2}{*}{ Valid Values } & 1 & Male & 186 & $39.1 \%$ \\
\hline & 2 & Female & 290 & $60.9 \%$ \\
\hline \multicolumn{2}{|c|}{ 3. Education } & Value & Count & Percent \\
\hline \multirow{3}{*}{ Valid Values } & 1 & Diploma & 2 & $0.4 \%$ \\
\hline & 2 & Undergraduate & 34 & $7.1 \%$ \\
\hline & 3 & Postgraduate & 440 & $92.4 \%$ \\
\hline \multicolumn{2}{|c|}{ 4. OBA } & Value & Count & Percent \\
\hline \multirow{2}{*}{ Valid Values } & 1 & Yes & 428 & $89.9 \%$ \\
\hline & 2 & No & 48 & $10.1 \%$ \\
\hline \multicolumn{2}{|c|}{ 5. EBA } & Value & Count & Percent \\
\hline \multirow{2}{*}{ Valid Values } & 1 & Yes & 446 & $93.7 \%$ \\
\hline & 2 & No & 30 & $6.3 \%$ \\
\hline
\end{tabular}




\begin{tabular}{|c|c|c|c|c|}
\hline \multicolumn{2}{|c|}{ 6. BAM } & Value & Count & Percent \\
\hline \multirow{3}{*}{ Valid Values } & 1 & $1-15$ & 208 & $43.7 \%$ \\
\hline & 2 & $16-30$ & 94 & $19.7 \%$ \\
\hline & 3 & $31-50$ & 174 & $36.6 \%$ \\
\hline \multicolumn{2}{|c|}{ 7. UBE } & Value & Count & Percent \\
\hline \multirow{2}{*}{ Valid Values } & 1 & $1-10$ & 336 & $70.6 \%$ \\
\hline & 2 & $>10$ & 140 & $29.4 \%$ \\
\hline
\end{tabular}

Note: OBA: Do you have an online bank account?, EBA: Have you ever accessed your Electronic Bank account?, BAM: How many times do you usually use your bank account in months?, UEB: How long have you been using Electronic Banking?.

Source: Own elaboration

calculated for the sample $(\mathrm{N}=476)$ by SPSS V.24. Table 3 shows the demographic information of the respondents. A majority of the respondents (60.9\%) are females in the age group (76.9\%) of $18-40$ years with postgraduate (92.4\%) degree and they have bank accounts (89.9\%).

\section{INDICATOR RELIABILITY}

According to Hair et al., (2017) indicator reliability is the first test to assess the evaluation of measurement models in PLS-SEM, for the purpose of testing the inner validity and reliability for the model. The measurement model is intended to assess the validity (convergent and discriminant) and reliability of each indicator forming latent constructs. After a PLS Algorithm has been run, first of all, the average variance extracted (AVE) must be checked. A general rule of thumb for AVE is $(\geq+.5)$ (Hair et al., 2017, p. 138). In reflective models, outer loading must be checked. Outer loadings represent the absolute contribution of the indicator to the definition of its latent variable (David Garson, 2016, p. 60). The rule of thumb for outer loadings between 0.40 and 0.70 is acceptable (Hair et al., 2017, p.131), hence, some indicators below 0.4 such as (SI14, SI15, SI16, FC21, FC23R, A57R) have been removed. According to Hulland (1999, p. 198) in social science studies, it is possible to have outer loadings $(<0.70)$. Table 4 shows the Evaluation of Measurement Model. Figure 1 shows evaluation of measurement model.

Table 4: Evaluation of Measurement Model with Attitude as a Moderator

\begin{tabular}{|c|c|c|c|c|c|c|}
\hline $\begin{array}{l}\text { Indicators/ } \\
\text { Items }\end{array}$ & Code & $\mathbf{F L}^{\mathbf{a}}$ & $\begin{array}{c}\text { Cronbach's } \\
\text { Alphab }^{b}\end{array}$ & Rho_A & $C R^{d}$ & AVE $_{c}$ \\
\hline \multirow[t]{6}{*}{ PE } & PE1 & 0.813 & 0.906 & 0.911 & 0.93 & 0.681 \\
\hline & PE2 & 0.83 & & & & \\
\hline & PE3 & 0.808 & & & & \\
\hline & PE4 & 0.905 & & & & \\
\hline & PE5 & 0.75 & & & & \\
\hline & PE6 & 0.839 & & & & \\
\hline \multirow[t]{6}{*}{ EE } & EE7 & 0.889 & 0.954 & 0.954 & 0.96 & 0.812 \\
\hline & EE8 & 0.917 & & & & \\
\hline & EE9 & 0.936 & & & & \\
\hline & EE10 & 0.883 & & & & \\
\hline & EE11 & 0.882 & & & & \\
\hline & EE12 & 0.898 & & & & \\
\hline \multirow[t]{3}{*}{ SI } & SI13 & 0.845 & 0.824 & 0.824 & 0.9 & 0.742 \\
\hline & SI17 & 0.916 & & & & \\
\hline & SI18 & 0.82 & & & & \\
\hline FC & FC19 & 0.907 & 0.847 & 0.853 & 0.91 & 0.767 \\
\hline
\end{tabular}




\begin{tabular}{|c|c|c|c|c|c|c|}
\hline & FC20 & 0.899 & & & & \\
\hline & FC22 & 0.818 & & & & \\
\hline \multirow[t]{18}{*}{ IF } & PE1 & 0.766 & 0.942 & 0.949 & 0.95 & 0.505 \\
\hline & PE2 & 0.76 & & & & \\
\hline & PE3 & 0.614 & & & & \\
\hline & PE4 & 0.756 & & & & \\
\hline & PE5 & 0.616 & & & & \\
\hline & PE6 & 0.742 & & & & \\
\hline & EE7 & 0.801 & & & & \\
\hline & EE8 & 0.803 & & & & \\
\hline & EE9 & 0.838 & & & & \\
\hline & EE10 & 0.778 & & & & \\
\hline & EE11 & 0.77 & & & & \\
\hline & EE12 & 0.779 & & & & \\
\hline & SI13 & 0.572 & & & & \\
\hline & SI17 & 0.553 & & & & \\
\hline & SI18 & 0.56 & & & & \\
\hline & FC19 & 0.672 & & & & \\
\hline & FC20 & 0.698 & & & & \\
\hline & FC22 & 0.608 & & & & \\
\hline$A *$ IF & IF * A & 1.811 & 1 & 1 & 1 & 1 \\
\hline \multirow[t]{5}{*}{ A } & A52 & 0.943 & 0.917 & 0.959 & 0.94 & 0.765 \\
\hline & A53 & 0.547 & & & & \\
\hline & A54 & 0.941 & & & & \\
\hline & A55 & 0.93 & & & & \\
\hline & A56 & 0.941 & & & & \\
\hline \multirow[t]{5}{*}{ UB } & UB64 & 0.933 & 0.912 & 0.937 & 0.94 & 0.755 \\
\hline & UB65 & 0.936 & & & & \\
\hline & UB66 & 0.934 & & & & \\
\hline & UB67 & 0.901 & & & & \\
\hline & UB68 Group & 0.588 & & & & \\
\hline
\end{tabular}

Note: FL: Factor Loading, PE: Performance Expectancy, EE: Effort Expectancy, SI: Social Influence, FC: Facilitating Conditions, IF: Individual Factors, A * IF: Attitude * Individual Factors, A: Attitude, and UB: User Behaviour.

Source: Own elaboration

\section{DISCRIMINANT VALIDITY MEASUREMENT}

Discriminant validity is defined as the extent to which a construct is truly distinct from other constructs by empirical standards (Hair et al., 2017). The function (PLS Algorithm) run in order to get each of the cross loadings, (Fornell \& Larcker Criterion) and the heterotrait-monotrait ratio (HTMT). This approach gives opportunities to researchers to be able to test each indicator that has strong loadings on the same factor and with multiple factors based on PLSSEM (Henseler et al., 2014). According to Hair et al. (2017, p.138), "an indicator's outer loading on the associated construct should be greater than any of its cross-loadings (i.e., its correlation) on other constructs". This study has calculated the discriminant validity of the first approach which is cross loading. All constructs met the criteria for discriminant validity. Table 5 shows Indicator Items Cross loading. 
Figure 1: Evaluation of Measurement Model

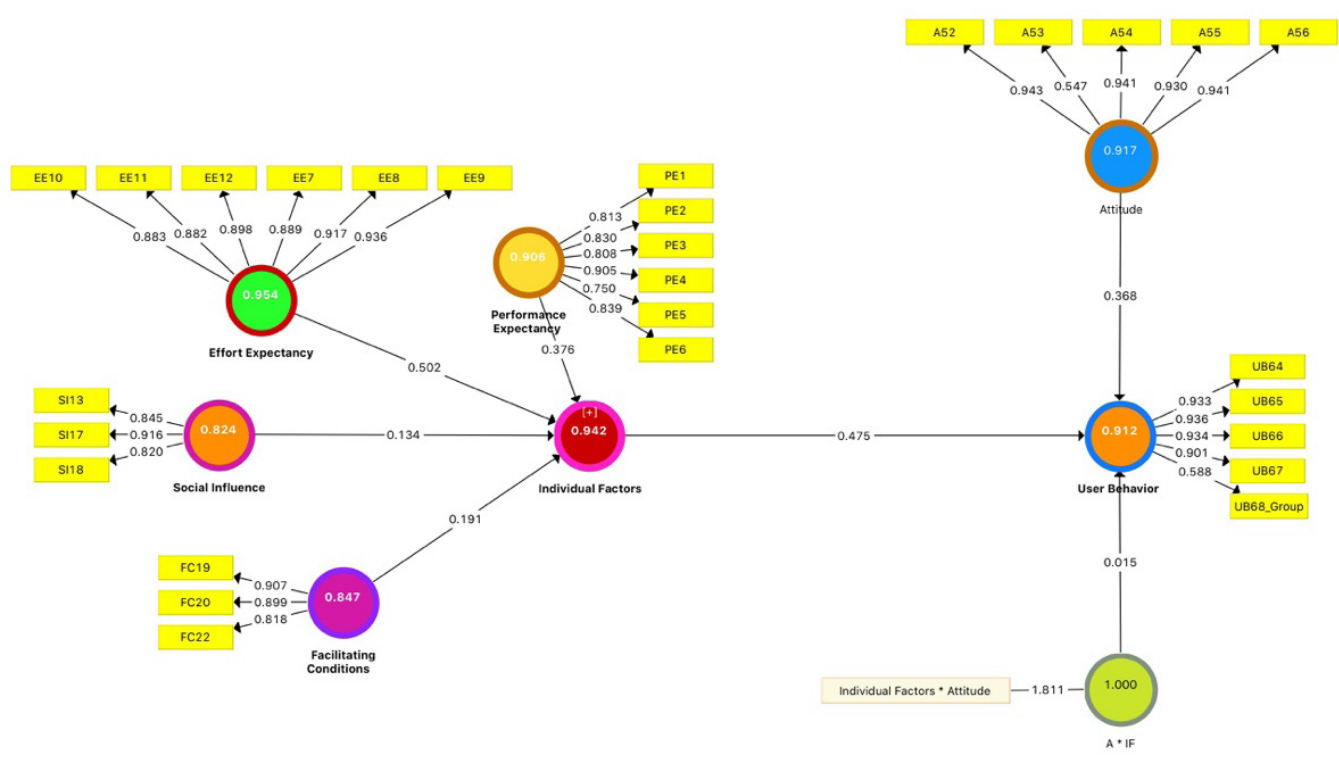

Source: Own elaboration

Table 5: Indicator Items Cross loading

\begin{tabular}{|c|c|c|c|c|c|c|c|c|}
\hline Construct & $A * I F$ & A & EE & FC & IF & PE & $\mathrm{SI}$ & UB \\
\hline A52 & -0.48 & 0.943 & 0.536 & 0.307 & 0.502 & 0.39 & 0.19 & 0.614 \\
\hline A53 & -0.446 & 0.547 & 0.226 & 0.38 & 0.401 & 0.42 & 0.461 & 0.258 \\
\hline A54 & -0.454 & 0.941 & 0.565 & 0.314 & 0.503 & 0.35 & 0.195 & 0.604 \\
\hline A55 & -0.488 & 0.93 & 0.601 & 0.361 & 0.563 & 0.416 & 0.264 & 0.575 \\
\hline A56 & -0.508 & 0.941 & 0.633 & 0.337 & 0.578 & 0.427 & 0.246 & 0.607 \\
\hline EE10 & -0.495 & 0.572 & 0.883 & 0.463 & 0.778 & 0.529 & 0.355 & 0.614 \\
\hline EE10 & -0.495 & 0.572 & 0.883 & 0.463 & 0.778 & 0.529 & 0.355 & 0.614 \\
\hline EE11 & -0.539 & 0.542 & 0.882 & 0.457 & 0.77 & 0.507 & 0.36 & 0.658 \\
\hline EE11 & -0.539 & 0.542 & 0.882 & 0.457 & 0.77 & 0.507 & 0.36 & 0.658 \\
\hline EE12 & -0.541 & 0.557 & 0.898 & 0.458 & 0.779 & 0.514 & 0.347 & 0.599 \\
\hline EE12 & -0.541 & 0.557 & 0.898 & 0.458 & 0.779 & 0.514 & 0.347 & 0.599 \\
\hline EE7 & -0.49 & 0.502 & 0.889 & 0.437 & 0.801 & 0.597 & 0.353 & 0.546 \\
\hline EE7 & -0.49 & 0.502 & 0.889 & 0.437 & 0.801 & 0.597 & 0.353 & 0.546 \\
\hline EE8 & -0.541 & 0.57 & 0.917 & 0.505 & 0.803 & 0.52 & 0.382 & 0.559 \\
\hline EE8 & -0.541 & 0.57 & 0.917 & 0.505 & 0.803 & 0.52 & 0.382 & 0.559 \\
\hline EE9 & -0.53 & 0.551 & 0.936 & 0.503 & 0.838 & 0.609 & 0.328 & 0.615 \\
\hline EE9 & -0.53 & 0.551 & 0.936 & 0.503 & 0.838 & 0.609 & 0.328 & 0.615 \\
\hline FC19 & -0.458 & 0.385 & 0.525 & 0.907 & 0.672 & 0.443 & 0.499 & 0.486 \\
\hline FC19 & -0.458 & 0.385 & 0.525 & 0.907 & 0.672 & 0.443 & 0.499 & 0.486 \\
\hline FC20 & -0.409 & 0.34 & 0.504 & 0.899 & 0.698 & 0.558 & 0.459 & 0.54 \\
\hline FC20 & -0.409 & 0.34 & 0.504 & 0.899 & 0.698 & 0.558 & 0.459 & 0.54 \\
\hline FC22 & -0.42 & 0.242 & 0.332 & 0.818 & 0.608 & 0.536 & 0.659 & 0.274 \\
\hline FC22 & -0.42 & 0.242 & 0.332 & 0.818 & 0.608 & 0.536 & 0.659 & 0.274 \\
\hline IF $* A$ & 1 & -0.532 & -0.58 & -0.489 & -0.632 & -0.52 & -0.387 & -0.469 \\
\hline PE1 & -0.456 & 0.455 & 0.655 & 0.43 & 0.766 & 0.813 & 0.329 & 0.599 \\
\hline PE1 & -0.456 & 0.455 & 0.655 & 0.43 & 0.766 & 0.813 & 0.329 & 0.599 \\
\hline
\end{tabular}




\begin{tabular}{|c|c|c|c|c|c|c|c|c|}
\hline PE2 & -0.493 & 0.474 & 0.644 & 0.434 & 0.76 & 0.83 & 0.278 & 0.593 \\
\hline PE2 & -0.493 & 0.474 & 0.644 & 0.434 & 0.76 & 0.83 & 0.278 & 0.593 \\
\hline PE3 & -0.383 & 0.223 & 0.298 & 0.468 & 0.614 & 0.808 & 0.568 & 0.24 \\
\hline PE3 & -0.383 & 0.223 & 0.298 & 0.468 & 0.614 & 0.808 & 0.568 & 0.24 \\
\hline PE4 & -0.508 & 0.4 & 0.518 & 0.521 & 0.756 & 0.905 & 0.432 & 0.439 \\
\hline PE4 & -0.508 & 0.4 & 0.518 & 0.521 & 0.756 & 0.905 & 0.432 & 0.439 \\
\hline PE5 & -0.27 & 0.204 & 0.306 & 0.528 & 0.616 & 0.75 & 0.625 & 0.275 \\
\hline PE5 & -0.27 & 0.204 & 0.306 & 0.528 & 0.616 & 0.75 & 0.625 & 0.275 \\
\hline PE6 & -0.433 & 0.376 & 0.512 & 0.521 & 0.742 & 0.839 & 0.54 & 0.454 \\
\hline PE6 & -0.433 & 0.376 & 0.512 & 0.521 & 0.742 & 0.839 & 0.54 & 0.454 \\
\hline SI13 & -0.352 & 0.208 & 0.331 & 0.513 & 0.572 & 0.526 & 0.845 & 0.198 \\
\hline SI13 & -0.352 & 0.208 & 0.331 & 0.513 & 0.572 & 0.526 & 0.845 & 0.198 \\
\hline SI17 & -0.291 & 0.181 & 0.29 & 0.572 & 0.553 & 0.468 & 0.916 & 0.217 \\
\hline SI17 & -0.291 & 0.181 & 0.29 & 0.572 & 0.553 & 0.468 & 0.916 & 0.217 \\
\hline SI18 & -0.354 & 0.316 & 0.392 & 0.486 & 0.56 & 0.416 & 0.82 & 0.299 \\
\hline SI18 & -0.354 & 0.316 & 0.392 & 0.486 & 0.56 & 0.416 & 0.82 & 0.299 \\
\hline UB64 & -0.43 & 0.581 & 0.615 & 0.481 & 0.635 & 0.515 & 0.279 & 0.933 \\
\hline UB65 & -0.466 & 0.643 & 0.607 & 0.446 & 0.613 & 0.486 & 0.281 & 0.936 \\
\hline UB66 & -0.424 & 0.562 & 0.625 & 0.426 & 0.618 & 0.507 & 0.219 & 0.934 \\
\hline UB67 & -0.459 & 0.608 & 0.606 & 0.381 & 0.569 & 0.427 & 0.215 & 0.901 \\
\hline UB68 Group & -0.208 & 0.269 & 0.398 & 0.485 & 0.476 & 0.409 & 0.205 & 0.588 \\
\hline
\end{tabular}

Source: Own elaboration

\section{(FORNELL AND LARCKER CRITERION)}

The Fornell and Larcker Criterion is the second measurement that can compare the correlations of the latent variable with the square root of the AVE values of $(0.50)$, the square root of the AVE of each construct should be higher than its highest correlation with any other construct. In other words, the outer of the indicator loadings should be higher than all its cross loadings with other constructs (Hair et al., 2017, p.139). All constructs met the criteria for discriminant validity. Table 6 shows
Discriminant Validity (Fornell \& Larcker Criterion).

\section{THE HETEROTRAIT-MONOTRAIT RATIO (HTNT)}

The heterotrait-monotrait ratio (HTMT) is the third measurement in order to test discriminant validity. According to G. David Garson (2016, p.70), the HTMT ratio should be below 1.0, which means the heterotrait correlations should be smaller than monotrait correlations. On the other hand, Henseler et al. (2015, p.121) proposed

Table 6: Discriminant Validity (Fornell and Larcker Criterion)

\begin{tabular}{|c|c|c|c|c|c|c|c|}
\hline Construct & A $*$ IF & A & EE & FC & IF & PE \\
\hline A * IF & $\mathbf{1}$ & & & & & \\
\hline A & -0.532 & $\mathbf{0 . 8 7 5}$ & & & & \\
\hline EE & -0.58 & 0.609 & $\mathbf{0 . 9 0 1}$ & & & \\
\hline FC & -0.489 & 0.371 & 0.522 & $\mathbf{0 . 8 7 6}$ & & \\
\hline IF & -0.632 & 0.58 & 0.882 & 0.754 & $\mathbf{0 . 7 1 1}$ & \\
\hline PE & -0.52 & 0.441 & 0.607 & 0.584 & 0.865 & $\mathbf{0 . 8 2 5}$ & \\
\hline SI & -0.387 & 0.273 & 0.393 & 0.609 & 0.653 & 0.547 & $\mathbf{0 . 8 6 1}$ \\
\hline UB & -0.469 & 0.629 & 0.663 & 0.501 & 0.672 & 0.539 & 0.276 \\
\hline
\end{tabular}

Source: Own elaboration 
Table 7: Discriminant Validity (HTMT)

\begin{tabular}{|c|c|c|c|c|c|c|c|c|}
\hline $\begin{array}{c}\text { Construct } \\
\text { A * IF }\end{array}$ & A * IF & A & EE & FC & IF & PE & SI & UB \\
\hline A & 0.573 & & & & & & & \\
\hline EE & 0.594 & 0.633 & & & & & & \\
\hline FC & 0.533 & 0.444 & 0.576 & & & & & \\
\hline IF & 0.644 & 0.615 & 0.887 & 0.872 & & & & \\
\hline PE & 0.54 & 0.499 & 0.637 & 0.672 & 0.946 & & \\
\hline SI & 0.425 & 0.36 & 0.443 & 0.737 & 0.809 & 0.648 & & \\
\hline UB & 0.484 & 0.659 & 0.711 & 0.579 & 0.7 & 0.585 & 0.321 & \\
\hline
\end{tabular}

Source: Own elaboration

0.90 as an acceptable value for the HTMT. Hair et al. (2017, p.140) proposed that there is a true correlation between two constructs if they were well measured and disattenuated correlation can be referred to that true correlation. A disattenuated correlation between two constructs higher than 0.90 shows a lack of discriminant validity. In this study, there is a lack of discriminant validity between (PE and IF) that its disattenuated correlation is higher than 0.90. Table 7 shows Discriminant validity.

\section{EVALUATION OF THE STRUCTURAL MODEL IN PLS-SEM}

According to Hair et al. (2017) the second step is an evaluation of the structure of the model. The most important evaluation metrics for the structural model are Collinearity Statistics (Inner VIF), $\mathrm{R}^{2}$ value (explained variance), $F^{2}$ value, $Q^{2}$ (predictive relevance), $F^{2}$ and $Q^{2}$ Effect Size and the size and statistical significance of the structural path coefficients.

\section{TESTING COLLINEARITY STATISTICS (INNVER VIF)}

According to Hair et al. (2017) testing collinearity is the first test in order to evaluate the structural model. Hair et al. (2011) defined Collinearity as a potential issue in the structural model and that variance inflation factor (VIF), the rule of thumb for the VIF is the value of 5 or above usually can be a problem. The term VIF is derived from its square root (VIF) being the degree to which the standard error has been increased due to the presence of collinearity. Table 8 shows the results of the structural model for this study that was done by using SmartPLS
(V3.2.8).

\section{$\mathbf{R}^{2}$ SQUARE $\left(\mathbf{R}^{2}\right)$ VALUE}

In order to get $\mathrm{F}^{2}$ Effect Size, scholars need to get the $R^{2}$ value first based on the application of PLS-SEM. The $R^{2}$ value is the most important approach to evaluate the structural model that can measure the coefficient of determination $\mathrm{R}^{2}$ Square value. According to Hair et al. (2017, p. 209) the coefficient of determination $R^{2}$ Square is a measure of the model's predictive power and is calculated as the squared correlation between a specific endogenous construct's actual and predicted values and the rule of thumb for the $R^{2}$ value is between 0 to 1. On the other hand, Falk and Miller (1992) propose an R-squared value of 0.10 as a minimum acceptable level and Chin (1998), suggested that the values of $R^{2}$ that are above 0.67 are considered high, while values ranging from 0.33 to 0.67 are moderate, whereas values between 0.19 to 0.33 are weak and any $R^{2}$ values less than 0.19 are unacceptable. Nevertheless, (Henseler et al., 2009; Hair et al., 2018) suggested the rule of thumb for the $R^{2}$ values of $0.75,0.50$, and 0.25 can be considered substantial, moderate, and weak. Table 8 shows the results.

\section{$F^{2}$ VALUES}

Another important measurement to evaluate the structural model is F2 Square value. According to Chin (1998, p. 317), F2 values of 0,02, 0,15 and 0,35 determine if latent exogenous variables have a small, medium or large effect-size (Cohen, 1988). F2 the value indicates an exogenous construct's small, medium, or large effect, respectively, on an endogenous construct (Hair et al., 
Table 8: Structural model results

\begin{tabular}{|c|c|c|c|c|c|}
\hline Construct & VIF & R Square & R Square Adjusted & F $^{2}$ Square & $\mathbf{Q}^{\mathbf{2}}$ \\
\hline A * IF & 1.787 & - & - & 0.001 & - \\
\hline A & 1.618 & - & - & 0.181 & - \\
\hline EE & 1.699 & - & - & 837.21 & - \\
\hline FC & 1.973 & - & - & 104.143 & - \\
\hline IF & 1.933 & 1 & - & 0.253 & 0.485 \\
\hline PE & 2.03 & - & - & 392.292 & - \\
\hline SI & 1.745 & - & $\mathbf{1}$ & 58.207 & - \\
\hline UB & - & $\mathbf{0 . 5 3 8}$ & $\mathbf{0 . 5 3 5}$ (Moderate) & - & 0.389 \\
\hline
\end{tabular}

Source: Own elaboration

2017, p. 216). Table 8 shows the results.

\section{PLSPREDiCT}

According to Shmueli et al. (2016) scholars need to assess the PLSpredict approach instead of reporting model fit, which is a set of procedures for prediction with PLS path models and the evaluation of their predictive performance. Recently the PLS-SEM domain was rapidly extended and updated, therefore researchers need to be aware of any progress on the application of the PLS-SEM domain (Hair et al., 2019; Sharma et al., 2019; Evermann et al., 2016). In this study, PLSpredict has been assessed by running PLSpredict in SmartPLS V3.2.8 with $\mathrm{K}=10$. Shmueli et al. (2019) have recommended that setting $(k=10)$. PLSpredict procedure generates $k$-fold cross- validation. A fold is a subgroup of the total sample, and $\mathrm{k}$ is the number of subgroups. Since the data for this study is nonnormal (non-symmetrically distributed) the mean absolute error (MAE) prediction metric has been taken according to Shmueli et al. (2019). The results show that there the model lacks predictive power, based on Shmueli et al. (2019) rule of thumb when "PLS-SEM < LM for none of the indicators. If the PLS-SEM analysis (compared to the LM) yields lower prediction errors in terms of the MAE (or the RMSE) for none of the indicators, this indicates that the model lacks predictive power". Table 9 illustrates the results of this study that have been achieved based on Shmueli et al. (2019) suggested recommendation setting in the application of the PLSpredict approach by SmartPLS (V 3.2.8).

Table 9: PLSpredict assessment of manifest variables (original model)

\begin{tabular}{|c|c|c|c|c|}
\hline \multirow{2}{*}{ Item } & \multicolumn{2}{|c|}{ PLS-SEM } & \multirow{2}{*}{$\begin{array}{c}\text { LM } \\
\text { MAE }\end{array}$} & \multirow{2}{*}{$\begin{array}{c}\text { PLS-SEM - LM } \\
\text { MAE }\end{array}$} \\
\hline & MAE & $\mathbf{Q}^{2}$ predict & & \\
\hline PE5 & 0.634 & 0.408 & 0 & 0.634 \\
\hline SI13 & 0.606 & 0.371 & 0 & 0.606 \\
\hline PE4 & 0.404 & 0.556 & 0 & 0.404 \\
\hline EE11 & 0.458 & 0.58 & 0 & 0.458 \\
\hline EE10 & 0.444 & 0.594 & 0 & 0.444 \\
\hline PE6 & 0.382 & 0.55 & 0 & 0.382 \\
\hline PE3 & 0.634 & 0.396 & 0 & 0.634 \\
\hline EE9 & 0.405 & 0.678 & 0 & 0.405 \\
\hline SI18 & 0.467 & 0.316 & 0 & 0.467 \\
\hline PE1 & 0.481 & 0.512 & 0 & 0.481 \\
\hline EE7 & 0.425 & 0.621 & 0 & 0.425 \\
\hline FC22 & 0.651 & 0.404 & 0 & 0.651 \\
\hline PE2 & 0.488 & 0.507 & 0 & 0.488 \\
\hline FC19 & 0.513 & 0.457 & 0 & 0.513 \\
\hline
\end{tabular}




\begin{tabular}{|c|c|c|c|c|}
\hline SI17 & 0.659 & 0.338 & 0 & 0.659 \\
\hline EE8 & 0.413 & 0.627 & 0 & 0.413 \\
\hline FC20 & 0.501 & 0.486 & 0 & 0.501 \\
\hline EE12 & 0.428 & 0.591 & 0 & 0.428 \\
\hline UB67 & 0.536 & 0.415 & 0.453 & 0.125 \\
\hline UB64 & 0.632 & 0.452 & 0.507 & 0.08 \\
\hline UB65 & 0.539 & 0.476 & 0.459 & 0.15 \\
\hline UB68 Group & 0.786 & 0.175 & 0.636 & 0.098 \\
\hline UB66 & 0.6 & 0.422 & 0.502 & \\
\hline
\end{tabular}

Note: *PLS-SEM < LM for none of the indicators. If the PLS-SEM analysis (compared to the LM) yields lower prediction errors in terms of the MAE (or the RMSE) for none of the indicators, this indicates that the model lacks predictive power.

Source: Own elaboration

\section{HYPOTHESIS TESTING: BOOTSTRAPPING DIRECT EFFECT RESULTS}

Hypothesis testing has been obtained for the structural model for this study by a Bootstrapping procedure by using the one-tailed test rather than the two-tailed in order to minimize the type II error (Latan et al., 2018), with 5000 samples and Bias- Corrected and Accelerated (BCa) in SmartPLS V 3.2.8 which is shown in Table 10 and 11. Bootstrapping is a resampling approach that draws random samples (with replacement) from the data and uses these samples to estimate the path model multiple times under slightly changed data constellations (Hair et al., 2017, p.191). Chin (1998) suggested that since PLSSEM is a nonparametric approach, as a result, scholars need to assess the bootstrapping procedure to achieve statistical significance. In short, P-value and t-value can be achieved among other results which are very important to determine whether the path coefficient is significant or not by running the Bootstrapping function in SmartPLS. A $p$-value is equal to the probability of obtaining a t-value at least as extreme as the one that is observed, conditional on the null hypothesis being supported. In other words, the $p$-value is the probability of erroneously rejecting a true null hypothesis (i.e., assuming a significant path coefficient when in fact it is not significant)(Hair et al., 2017, p.206), the rule of thumb for $\mathrm{p}$-value is $\left(* * * P<0.001,{ }^{*} \mathrm{P}<0.01\right.$, $* \mathrm{P}<0.05)$ and for empirical $t$-value is above 1.96. From the Bootstrapping result of the structural model, the following hypothesis can be derived:

H1. Individual Factors have a positive effect on User Behaviour.

H1a. Attitude will not moderate the relationship between Individual Factors and User Behaviour.
The final measurement is moderation analysis, which is like multigroup analysis (Henseler \& Chin, 2010; Henseler et al., 2012; Hair et al., 2017, p.246; Becker et al., 2018; Alaaraj et al., 2016, 2018). Hair et al. (2017, p.246) described Moderation as "a situation in which the relationship between two constructs is not constant but depends on the values of a third variable, referred to as a moderator variable". Further, the Moderator variable can affect the relationship between the independent variables and dependent variables directly. In this study, the structural model has been tested one time, the structural model has been tested with the moderator (Attitude) by using SmartPLS V3.2.8 to run a moderation analysis. Rigdon et al. (2010) proposed bootstrapping with 5000 samples and Bias-Corrected and Accelerated (BCa) to analysis moderators, meanwhile, accordingly (Chin et al., 2003; Hair et al., 2019) suggested the twostage approach to moderator analysis. Table 10 shows the analysis results of second-order components which is IF which has been done with the repeated-indicators approach. Table 11 shows the Direct Relationship for Hypothesis testing included (Std Beta, Std Erro, t-value, p-Value, 5\% lower bounds and 95\% upper bounds). Figure 2 shows evaluation of the structural model. Figure 3 shows a simple slope analysis (Attitude * Individual Factors).

\section{IMPLICATIONS}

\section{THEORETICAL IMPLICATIONS}

According to the bunched studies that have been cited on the UTAUT, this research extended the UTAUT by adding Attitude as a moderator and used four of UTAUT's constructors as lower constructors for this research in 
Figure 2: Evaluation of Structural Model

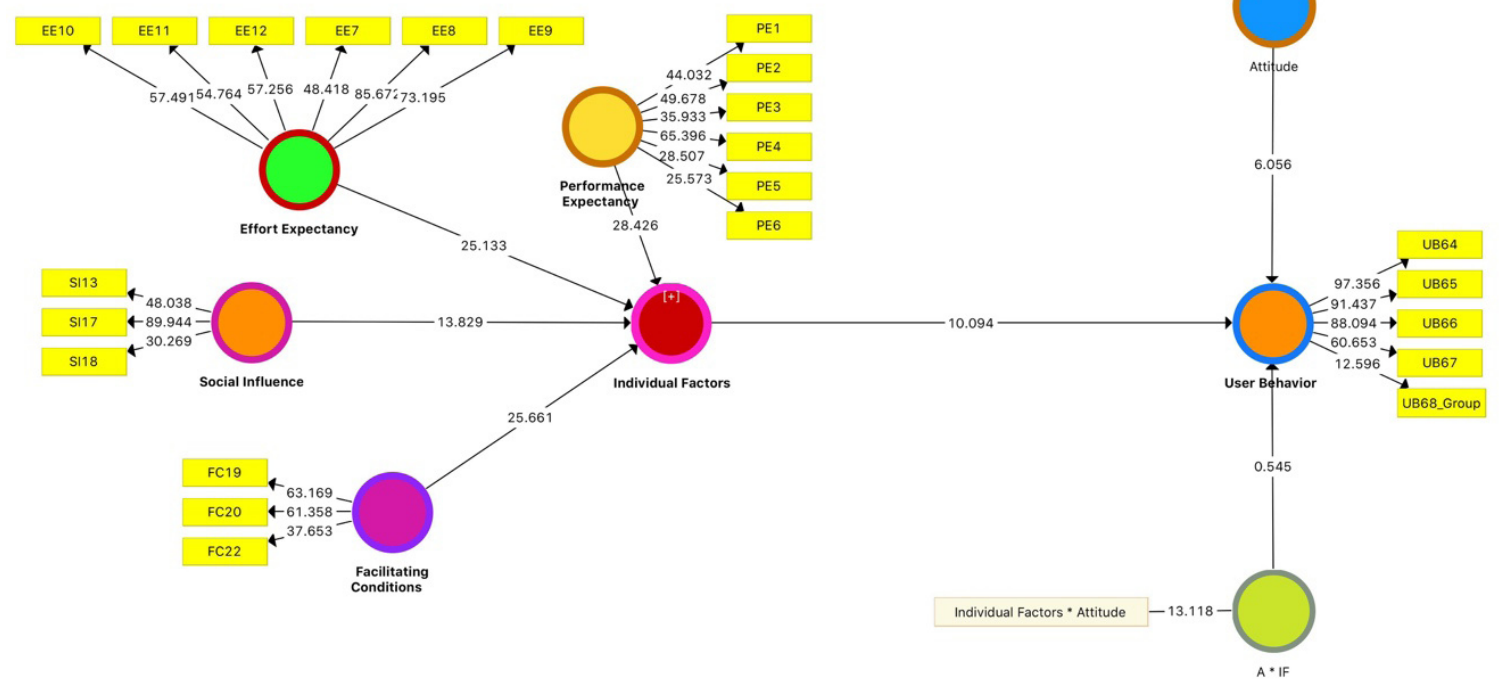

Source: Own elaboration

order to obtain the second order, namely Individual Factors thus to investigate the effect of Individual Factors on accepting E-banking in the KRI and the effect of Attitude as a moderator in this research. In this study, to get more concrete theoretically, on the other hand, to reduce the number of hypotheses in the path. Individual Factors were built as second-order components, besides, in this study we highlight the effect of Attitude that increased as a moderator in the research framework to understand the acceptance factors of E-banking services as a new technology service in the KRI. To the best of this researcher's knowledge, this study is the first empirical study in the KRI on E-banking, and provides a foundation for other studies in the future. Besides, it increases good literature in the absence of the existing literatures of E-banking.

\section{Practical implications}

With regard to the Managerial and the practical implications, this study shed light on the moderation effect of (attitude) on the direct effects of Individual factors on User Behaviour. The results showed that attitude has an insignificant and negative Moderator role on the relationship in the framework. The study results reveal that attitude is not an issue effecting customer decisions in order to accept E-banking; there are several important managerial and practical implications that can be derived from the results of the current study; it is assured that the results have great empirical evidence and it is very important for bank managers, bankers and strategic decision makers that are willing to employ E-Banking services. Therefore, this study recommend that bank managers should concentrate on increasing the level of other factors, for example by training or publishing some videos on the bank's website or sending such through personal email to its customers, in order to increase knowledge about how to learn to use E-banking channel services safely, specifically with the older generation, rather than losing money and time by travelling to bank branches (Alaarj et al., 2017a, 2017b).

Table 10: Analysis of Second-order variables

\begin{tabular}{|c|c|c|c|c|c|c|c|}
\hline $\begin{array}{c}\text { Second-order } \\
\text { components }\end{array}$ & $\begin{array}{c}\text { Lower-order } \\
\text { components }\end{array}$ & Std Beta & Std Error & \{t-value\} & P Values & $\begin{array}{c}\mathbf{5 \%} \text { lower } \\
\text { boundsision }\end{array}$ \\
\hline IF & PE & 0.376 & 0.013 & 28.426 & 0.000 & Supported & 0.355 \\
\hline IF & EE & 0.504 & 0.02 & 25.133 & 0.000 & Supported & 0.473 \\
\hline IF & SI & 0.133 & 0.01 & 13.829 & 0.000 & Supported & 0.116 \\
\hline IF & FC & 0.191 & 0.007 & 25.661 & 0.000 & Supported & 0.179 \\
\hline
\end{tabular}

Source: Own elaboration 
Table 11: Direct Relationship for Hypothesis testing with Attitude as a moderator

\begin{tabular}{|c|c|c|c|c|c|c|c|c|}
\hline Hypothesis & Relationship & Std Beta & Std Error & \{t-value\} & P Values & Decision & $\begin{array}{c}\text { 5\% lower } \\
\text { bounds }\end{array}$ & $\begin{array}{c}\mathbf{5} \% \text { upper } \\
\text { bounds }\end{array}$ \\
\hline H1 & IF->UB & 0.476 & 0.047 & 10.094 & 0.000 & Supported & 0.397 & 0.551 \\
\hline H1a & A $^{*}$ IF->UB & 0.013 & 0.028 & 0.545 & 0.293 & Rejected & -0.035 & 0.055 \\
\hline
\end{tabular}

\section{Source: Own elaboration}

Figure 3: Simple Slope analysis (Attitude * Individual Factors)

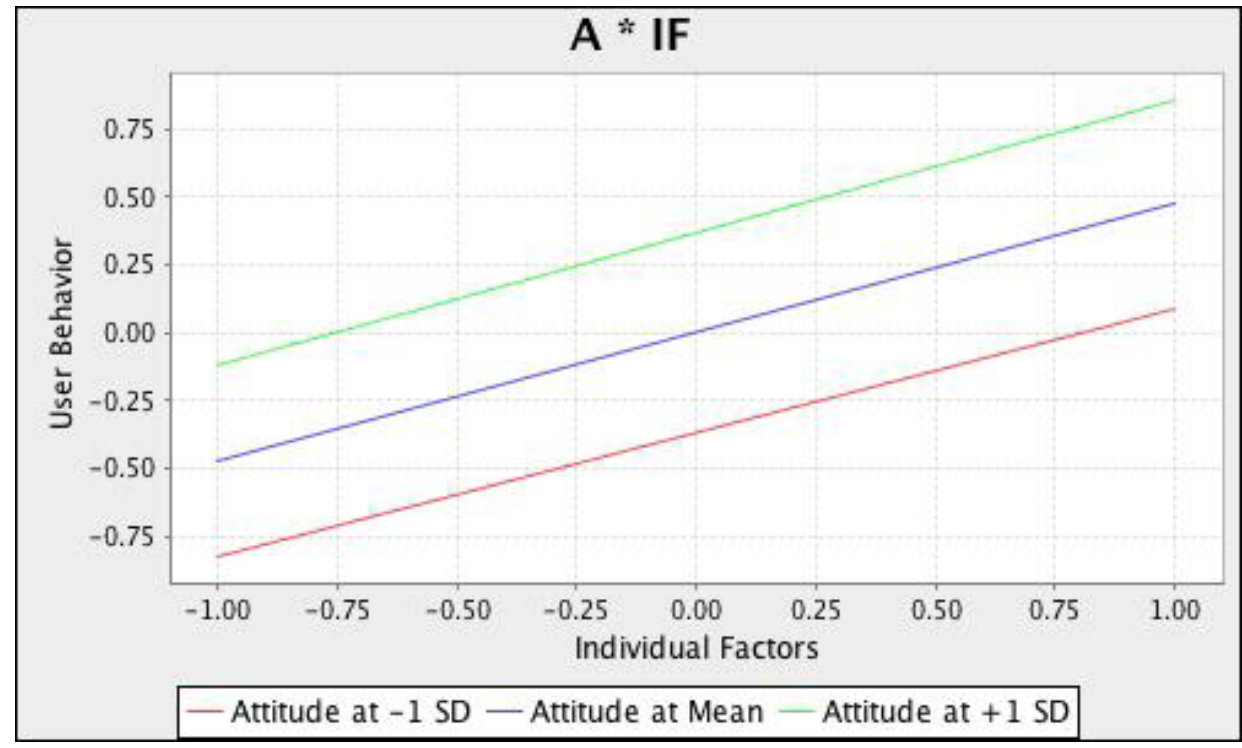

Source: Own elaboration

It is recommended that banks need to offer greater services with respect to E-banking. On the other hand, the result suggests that banks should have more marketing strategy guidelines, such as free of charge, increasing numbers and accessibility of ATMs, simplicity, using social media for sharing and increasing its experience rather than only for advertising (YouTube channel services, Facebook, Twitter, Instagram, etc.), 24/7 Customer Services (Call Centers) via free Skype services or costfree phone numbers, Kurdish Language and lower rates on loans or mortgages can change customers' attitude toward acceptance. Attitude is not a key concern affecting the customer's decision to accept E-banking. On the other hand, this study recommends the banks always understand customer complaints and what goes against customers' attitude through Research and Development (R\&D) and (Strength, Weakness, Opportunities and Threats) SWOT analysis. From the above discussion, this study recommends bank managers emphasize that there is not a need to concerning attitude in order to accept E-banking services. E-banking is a key concern affecting economic growth, it leads to a sustainable economy and sustainable environmental future in the KRI.

\section{LIMITATIONS AND FUTURE RESEARCH DIRECTIONS}

There are several limitations in this study that can be addressed and recommended for future studies. This research only tested attitude as a moderator, many other factors are beyond the domain of this study that can act as a moderator, such as (Culture, Word of mouth, Speed, Subject Norms, Religion etc.) (Khan, 2018; M. Hama Khan, 2019).UTAUT and TAM are the only two theories that the research framework is based on, other theories can be used in order to build the research frameworks as a base, such as (TRA, TPB, DTPB, IDT, UTAUT 2, etc.) (Khan, 2018; M. Hama Khan, 2019).There are conceptual limitations which mean there is no possibility to test every single potential hypothesis that can be drawn in the research framework. Moreover, further study must conceptualize and concentrate on specific channels of E-banking services such as Internet banking or ATMs since there are a limited number of ATMs in the KRI and there is no official number on it, except there is a report from the International Monetary Fund in (2018) that there are 611 ATMs in Iraq which is not a big number of ATMs 
compared to other developing countries. The data were collected from the academic university staff only at the University of Sulaimani through an online questionnaire which is considered a self-reporting bias which is a mutual difficulty in the methodology for scholars thus it is considered a popular issue among scholars, as a result, it cannot be generalised to E-banking in the KRI thus further research should collect data from each city in the KRI.

\section{CONCLUSIONS AND FUTURE RESEARCH}

The electronic banking system plays a major role in the financial industry. Moreover, it has simplified financial transactions thus, this article investigated E-banking services based on the unified theory of acceptance and use of technology (UTAUT) in the KRI, in order to investigate the moderating effect of attitude. This study proposed a conceptual model with (Individual Factor) as the independent variable, (User Behaviour) as the dependent variable, and (Attitude) as the moderating variable.(Individual Factor) is conceptualised as a second- order construct with four sub-dimension indicators, namely, (Performance Expectancy, Effort Expectancy, Social Influence, and Facilitating Condition). The study was done in two steps, the first steps was a systematic literature review related to E-banking services that the researcher prepared for this article based on empirical articles from different sources on E-banking, in order to have a robust theoretical framework for this study andto help researchers for future researches by using different methodologies and theories in order to build a stronger research framework. The second step was investigating the research model empirically, and employed PLS-SEM methods. The results showed that Individual Factors have a positive indirect impact on User Behaviour, but attitude has a negative effect on the relationship between Individual Factors and User Behaviour as a moderator (Giovanis et al., 2019; Chawla \& Joshi, 2017). Finally, the findings of this study are supportive for researchers, bank managerial and bank practitioners in order to provide a better quality of both offline and online banking services in the KRI.

\section{REFERENCES}

de Abrahão, R., Moriguchib, S.N., Andrade, D.F. (2016).Intention of Adoption of Mobile Payment: An Analysis in the Light of the Unified Theory of Acceptance and Use of Technology (UTAUT). Revista de Administração e Inovação RAl-21; No. of Pages 10. https://doi.org/10.1016/j.rai.2016.06.003.

Al-Qeisi, K.,Dennis C, Alamanos E, Jayawardhena C. (2014). Website Design Quality and Usage Behaviour: Unified Theory of Acceptance and Use of Technology. Journal of Business Research, 67(2014) 2282-2290. http://dx.doi.org/10.1016/j. jbusres.2014.06.016.

Alaarj, S., Mohamed, Z.A.,Bustamam, U.S.A. (2017a). Do Knowledge Management Capabilities Reduce the Negative Effect of Environment Uncertainties on Organizational Performance? A Study of Public Listed Companies in Malaysia. International Journal of Economic Research, 14(15), 443-456.

Alaarj, S., Mohamed, Z.A., Bustamam, U.S.A. (2017b). The Effect of Knowledge Management Capabilities on Performance of Companies : A Study of Service Sector. International Journal of Economic Research, 14(15), 457-470.

Alalwan, A.A., Baabdullah, A., Rana, N.P., Tamilmani, K, Dwivedi, Y.K. (2018). Examining Adoption of Mobile Internet in Saudi Arabia: Extending TAM with Perceived Enjoyment, Innovativeness and Trust. Technology in Society (2018).doi: 10.1016/j.techsoc.2018.06.007.

Alalwan, A.A., Yogesh, K., Dwivedi, Y.K., Rana, N.P., Algharabat, R. (2018). Examining Factors Influencing Jordanian Customers' Intentions and Adoption of Internet Banking: Extending UTAUT2 with Risk. Journal of Retailing and Consumer Services, 40(2018)125-138. http://dx.doi.org/10.1016/j.jretconser.2017.08.026.

Alalwan, A.A., Yogesh, K., Dwivedi, Y.K., Rana, N.P.(2017). Factors Influencing Adoption of Mobile Banking by Jordanian Bank Customers: Extending UTAUT2 with Trust. International Journal of Information Management, 37(3), 2017, 99110, https://doi.org/10.1016/j.ijinfomgt.2017.01.002.

Aljanabi, A. (2017). The Mediating Role of Absorptive Capacity on the Relationship between Entrepreneurial Orientation and Technological Innovation Capabilities. International Journal of Entrepreneurial Behaviour \& Research, 24(4), 818-841.https://doi.org/10.1108/ IJEBR-07-2017-0233. 
Aljanabi, A., Hamasaleh, S., Mohd Noor, N. (2019). Cultural Diversity and Operational Performance: Entrepreneurial Orientation as a Mediator. International Journal of Quality \& Reliability Management, 36(9), 1522-1539. https://doi. org/10.1108/IJQRM-10-2018-0262.

Aljanabi, A., AL-Hadban, W. (2018). Information Literacy and Learners' Satisfaction: The Mediating Role of Social Networking Technology Usage. Information and Learning Science, https://doi.org/10.1108/ILS-08-2018-0091.

Aljanabi, R.A., Dileep, K.M. (2012).Knowledge Sharing and Its Impact on Innovation Performance: A case study of Teaching Quality Assurance Program. RJCBS,2(2) December-2012.

Aljanabi, R.A., Dileep, K.M. (2013). Talent Management Strategy and Absorptive Capacity as Antecedences of Innovation Capability: A Conceptual Framework.RJSSM,2(9), January-2013.

Aljanabi, R.A., Mohd Noor, Nor Azila (2015)a. Critical Determinants of Technological Innovation: A Conceptual Framework and a Case Study from Iraq. International Business Research,8(2), 2015.

Aljanabi, R.A., Mohd Noor, Nor Azila (2015)b. The Mediating role of Market Orientation on Entrepreneurial Orientation, Absorptive Capacity and Technological Innovation Capabilities.Asian Social Science, 11(5), 2015.

Alkhaffaf, H., Aljanabi, A.R. (2016). Imperatives of Intellectual Capital and Technical Skills for Innovation: Perspective on Higher Education. International Journal of Information Technology \& Computer Science, 22(1). https://doi. org/10.1063/1.4960856.

Giovanis, A., Athanasopoulou, P., Assimakopoulos, C., Sarmaniotis, C. (2019). Adoption of Mobile Banking Services: A Comparative Analysis of Four Competing Theoretical Models. International Journal of Bank Marketing, https://doi. org/10.1108/IJBM-08-2018-0200.

Baabdullah, A., Alalwan, A., Rana, N.P., Patil, P., Kizgin, H. (2019). Consumer Use of Mobile Banking (M-Banking) in Saudi Arabia: Towards an Integrated Model International. Journal of Information Management 44(2019), 38-52, https:// doi.org/10.1016/j.ijinfomgt.2018.09.002.

Baabdullah, A., Alalwan, A., Rana, N., Patil, P., Dwivedi, Y. (2019). An Integrated Model for M-Banking Adoption in Saudi Arabia. International Journal of Bank Marketing, Vol. 37, No. 2, 452-478.https://doi.org/10.1108/IJBM-07-20180183.

Becker, J.-M., Ringle, C.M., Sarstedt, M. (2018). Estimating Moderating Effects in PLS-SEM and PLSc-SEM: Interaction Term Generation*Data Treatment (June 15, 2018). Journal of Applied Structural Equation Modeling, 2(2), 1-21, June 2018. Retrieved from SSRN: https://ssrn.com/abstract=3223421.

Bhatiasevi, V. (2016). An extended UTAUT model to explain the adoption of mobile banking. Information Development, 32(4), 799-814. https://doi.org/10.1177/0266666915570764.

Marakarkandy, B. Yajnik, N., Dasgupta, Ch. (2017). Enabling Internet Banking Adoption: An Empirical Examination with an Augmented Technology Acceptance Model (TAM). Journal of Enterprise Information Management, 30(2), 263294, https://doi.org/10.1108/JEIM-10-2015-0094.

Bunt, H. van de. (2008). A Case Study on the Misuse of Hawala Banking. International Journal of Social Economics, 35(9), 691-702. https://doi.org/10.1108/03068290810896316.

Ayo, C., Oni, A., Adewoye, O., Eweoya, I. (2016). E-banking Users' Behaviour: E-service Quality, Attitude, and Customer Satisfaction. International Journal of Bank Marketing, 34 (3), 347-367. https://doi.org/10.1108/IJBM-12-20140175.

Chawla, D., Joshi, H. (2017). High Versus Low Consumer Attitude and Intention Towards Adoption of Mobile Banking in India: An Empirical Study. Vision, 21(4), 410-424. https://doi.org/10.1177/0972262917733188.

Chawla, D., Joshi, H. (2018). The Moderating Effect of Demographic Variables on Mobile Banking Adoption: An Empirical Investigation. Global Business Review, 19(3_suppl), S90-S113. https://doi.org/10.1177/0972150918757883.

Chin, W.W. (1998). The Partial Least Squares Approach to Structural Equation Modeling. In G. A.Marcoulides (Ed.), Modern methods for business research (pp. 295-358). Mahwah, NJ: LawrenceErlbaum.

Chin, W.W., Marcolin, B.L., Newsted, P.R. (2003). A partial Least Squares Latent Variablemodeling Approach for Measuring Interaction Effects: Results from a Monte Carlo Simulation Studyand an Electronic-Mail Emotion/Adoption Study. Information Systems Research, 14, 189-217.

Claro, D.P., Rosa, R.B. (2016). Drivers Leading Firm Adoption of Internet Banking Services. Marketing Intelligence \& 
Planning, 34(3), 336-354, https://doi.org/10.1108/MIP-11-2015-0226.

Davis, F.D., Bagozzi, R.P., Warshaw, P.R. (1989). User Acceptance of Computer Technology: A Comparison of Two Theoretical Models. Management Science, 35, 1989, 982-1003. https://doi.org/10.1287/mnsc.35.8.982.

Davis, F.D. (1989). Perceived Usefulness, Perceived Ease of Use, and User Acceptance of Information Technology. MIS Quarterly 13(3), 319-40. doi:10.2307/249008.

de Goede, M. (2003). Hawala Discourses and the War on Terrorist Finance. Environment and Planning D: Society and Space, 21(5), 513-532. https://doi.org/10.1068/d310t.

Abushanab, E., Pearson, J.M. (2007). Internet Banking In Jordan: The Unified Theory Of Acceptance and Use of Technology (UTAUT) perspective. Journal of Systems and Information Technology, 9(1),78-97. https://doi. org/10.1108/13287260710817700.

Daniel, E. (1999). Provision of Electronic Banking in the UK and the Republic of Ireland. International Journal of Bank Marketing, 17(2), pp.72-83, https://doi.org/10.1108/02652329910258934.

Evermann, J., Tate, M. (2016). Assessing the Predictive Performance of Structural Equation Model Estimators. Journal of Business Research, 69(10), 4565-4582. http://dx.doi.org/10.1016/j.jbusres.2016.03.050.

Tan, E., Lau, J.L. (2016). Behavioural Intention to Adopt Mobile Banking Among the Millennial Generation. Young Consumers, 17(1), 18-31. https://doi.org/10.1108/YC-07-2015-00537.

Muñoz-Leiva, F., Climent-Climent, S., Liébana-Cabanillas, F. (2017). Determinants of Intention to use The Mobile Banking Apps: An Extension of the Classic TAM Model. Spanish Journal of Marketing - ESIC (2017) 21, 25-38. https:// doi.org/10.1016/j.sjme.2016.12.001.

Faith, D.C. (2011). The Hawala System. Global Security Studies, 2(1), 11. Retrieved from http://www.imf.org/external/ pubs/ft/fandd/2002/12/elqorchi.htm.

Fen Lin. H. (2011). An Empirical Investigation of Mobile Banking Adoption: The Effect of Innovation Attributes and Knowledge-based Trust. International Journal of Information Management, 31(2011), 252-260. doi:10.1016/j. ijinfomgt.2010.07.006.

Floh, A., Treiblmaier, H. (2006). What Keeps the E-Banking Customer Loyal? A Multigroup Analysis of the Moderating Role of Consumer Characteristics on E-Loyalty in the Financial Service Industry. (March 26, 2006). http://dx.doi. org/10.2139/ssrn.2585491.

Shmueli, G., Sarstedt, M., Hair, J.F., Jun-Hwa Ch., Ting, H., Vaithilingam, S., Ringle, C.M. (2019). Predictive Model Assessment in PLS-SEM: Guidelines for Using PLSpredict. European Journal of Marketing, https://doi.org/10.1108/ EJM-02-2019-0189.

Garson, G.D. (2016). Partial Least Squares: Regression \& Structural Equation Models (2016 Editi). Statistical Associates Publishing. Retrieved from www.statisticalassociates.com.

Baptista, G., Oliveira, T. (2015). Understanding Mobile Banking: The Unified Theory of Acceptance and Use of Technology Combined with Cultural Moderators. Computers in Human Behaviour, Volume 50, 2015, 418-430. https:// doi.org/10.1016/j.chb.2015.04.024.

Hair, J.F., Hult, G.T.M., Ringle, C.M., Sarstedt, M. (2017). A Primer on Partial Least Squares Structural Equation Modeling (PLS-SEM), 2nd Ed., Sage: Thousand Oaks.

Hanafizadeh, P., Khedmatgozar, H.R (2012). The Mediating Role of the Dimensions of the Perceived Risk in the Effect of Customers' Awareness on the Adoption of Internet Banking in Iran. Electronic Commerce Research, (2012), 12(2), 151-175. https://doi.org/10.1007/s10660-012-9090-z.

Hoehle, H., Scornavacca, E., Huff, S. (2012). Three Decades of Research on Consumer Adoption and Utilization of Electronic Banking Channels: A Literature Analysis. Decision Support Systems, 54(1), 2012, 122-132, ISSN 0167-9236, https://doi.org/10.1016/j.dss.2012.04.010.

Henseler, J., Chin, W.W. (2010). A Comparison of Approaches for the Analysis of Interaction Effects Between Latent Variables Using Partial Least Squares Path Modeling. Structural Equation Modeling: A Multidisciplinary Journal, 17(1), 82-109.

Henseler, J., Ringle, C.M., Sarstedt, M. (2016). Testing Measurement Invariance of Composites Using Partial Least Squares. International Marketing Review, 33(3), 405-431. 
Henseler, J., Fassott, G., Dijkstra, T., Wilson, B. (2012). Analysing Quadratic Effects of Formative Constructs by Means of Variance-Based Structural Equation Modelling. European Journal of Information Systems, 21(1), 99-112.

Henseler, J., Ringle, C.M., Sinkovics, R.R. (2009). The Use of Partial Least Squares Path Modeling in International Marketing, in Advances in International Marketing, R.R. Sinkovics, P.N. Ghauri (eds.), Emerald: Bingley, $277-320$. https://doi.org/10.1007/s10551-016-3318-0.

Henseler, J., Dijkstra, T.K., Sarstedt, M., Ringle, C.M., Diamantopoulos, A., Straub, D.W., Ketchen, D.J. Jr., Hair, J.F., Hult, G.T.M., Calantone, R.J. (2014). Common Beliefs and Reality Aboutpls: Comments on Rönkkö and Evermann (2013). Organizational Research Methods, 17(2), 182-209.

Ting, H., Yusman, Y., Liew, L., Wee Ming Lau (2016). Intention to Use Mobile Payment System: A Case of Developing Market by Ethnicity. Procedia - Social and Behavioural Sciences 224(2016), 368 - 375. doi: 10.1016/j.sbspro.2016.05.390.

Hoehle, H., Kude, T., Huff, S., Popp, K. (2016). Service-Channel Fit Conceptualization and Instrument Development A Mixed Methods Study in the Context of Electronic Banking, Business \& Information Systems Engineering, Issue 2, DOI 10.1007/s12599-015-0415-z.

Huang, S.M., Shen, W.-C., Yen, D.-C., Chou., L.-Y. (2011). IT Governance: Objectives and Assurances in Internet Banking, Advances in Accounting. Incorporating Advances in International Accounting, 27 (2011), 406-414. https://doi org/10.1016/j.adiac.2011.08.001.

Hulland, J. (1999). Use Of Partial Least Squares (PLS) In Strategic Management Research: A Review Offour Recent Studies. Strategic Management Journal, 20, 195-204.

Tran, H., Corner, J. (2016). The Impact of Communication Channels on Mobile Banking Adoption. International Journal of Bank Marketing, 34(1), 78-109, https://doi.org/10.1108/IJBM-06-2014-0073.

Ajzen, I. (1991). The Theory of Planned Behaviour, Or Hum. Decis. Process. 50(2) (1991) 179- 211. https://doi. org/10.1016/0749-5978(91)90020g.

Mansour, I.H.F., Eljelly, A.M.A., Abdullah, A.M.A. (2016). Consumers' Attitude Towards E-banking Services in Islamic Banks: the Case of Sudan. Review of International Business and Strategy, 26(2), 244-260. https://doi.org/10.1108/ RIBS-02-2014-0024.

International Monetary Fund (2019). Geographical Outreach: Number of Automated Teller Machines (ATMs), Country Wide for Iraq [IRQFCACNUM]. Retrieved from FRED, Federal Reserve Bank of St. Louis; https://fred.stlouisfed.org series/IRQFCACNUM, December 16.

Ismail, A.A. (2007). Lawlessness and Economic Governance: The Case of Hawala System in Somalia. International Journal of Development Issues, 6(2), 168-185.https://doi.org/10.1108/14468950710843415.

Sánchez-Torres, J., Canada, F., Sandoval, A. and Alzate, J. (2018). E-banking in Colombia: Factors Favouring its Acceptance, Online Trust and Government Support. International Journal of Bank Marketing, https://doi.org/10.1108/IJBM-102016-0145.

Hair, J., Hollingsworth, C.L., Randolph, A.B., Chong, A.Y.L (2017). An Updated and Expanded Assessment of PLS-SEM in Information Systems Research. Industrial Management \& Data Systems, 117(3), 442-458. https://doi.org/10.1108/ IMDS-04-2016-0130.

Hair, J.F., Risher, J.J., Sarstedt, M., Ringle, C.M. (2019). When to Use and How to Report the Results of PLS-SEM. European Business Review, 31(1), 2-24, https://doi.org/10.1108/EBR-11-2018-0203.

Hair, J.F., Risher, J.J., Sarstedt, M., Ringle, C.M. (2019). Rethinking Some of the Rethinking of Partial Least Squares. European Journal ofMarketing, https://doi.org/10.1108/EJM-10-2018-0665 Permanent link to this document:https:// doi.org/10.1108/EJM-10-2018-0665.

Karjaluoto, H., Mattila, M., Pento, T. (2002). Electronic Banking in Finland: Consumer Beliefs and Reactions to a New Delivery Channel. Journal of Financial Services Marketing, 6(4), 346-361. https://doi.org/10.1057/palgrave.fsm.4770064.

Khan, Y. H. (2018). A Short Review of the Electronic Banking System. Regional and Business Studies, 10(1), 13-37. https:// doi.org/10.33568/rbs.2333.

Al-Qeisi, K., Hegazy, A. (2015). Consumer Online Behaviour: A Perspective on Internet Banking Usage in Three Nonwestern Countries. Procedia Economics and Finance,Volume 23, 2015, 386-390. https://doi.org/10.1016/S2212 5671(15)00347-0. 
Kingshott, R.P.J., Sharma, P., Chung, H.F.L., (2018). The Impact of Relational versus Technological Resources on E-loyalty: A Comparative Study between Local, National and Foreign Branded Banks. Industrial Marketing Management, 72(2018), 48-58, https://doi.org/10.1016/j.indmarman.2018.02.011.

Latan, H., Ringle, C.M., Jabbour, C.J.C. (2018). Whistleblowing Intentions Among Public Accountants in Indonesia: Testing for the Moderation Effects, J Bus Ethics, 152(2), 573-588.

Lee, E., Lee, J. (2000). Haven't Adopted Electronic Financial Services Yet? The Acceptance and Diffusion of Electronic Banking Technologies. Financial Counseling and Planning, 11(1), 49-61.

Liargovas, P., Repousis, S. (2011). Underground Banking or Hawala and Greece-Albania Remittance Corridor. Journal of Money Laundering Control, 14(4), 313- 323. https://doi.org/10.1108/13685201111173794.

Luarn, P., Lin, H.H. (2005). Toward an Understanding of the Behavioural Intention to Use Mobile Banking. Computers in Human Behaviour, 21(2005), 873-891. doi:10.1016/j.chb.2004.03.003.

Luo, X., Li, H., Zhang, J., Shim, J.P. (2010). Examining Multi-dimensional Trust and Multi-Faceted Risk in Initial Acceptance of Emerging Technologies: An Empirical Study of Mobile Banking Services. Decision Support Systems, 49 (2010), 222-234. doi:10.1016/j.dss.2010.02.008.

Fishbein, M., Ajzen, I. (1975). Attitude, Intention and Behaviour: An Introduction to Theory and Research. DOI: $10.2307 / 3033786$.

Hama Khan M., Yadgar (2019). An Essential Review of Internet Banking Services in Developing Countries. e-Finanse, 15(2), 73-86. doi: https://doi.org/10.2478/fiqf-2019-0013.

Sarstedt, M., Hair, J. F., Cheah, J.-H., Becker, J.-M., Ringle, C. (2019). How to Specify, Estimate, and Validate Higher-order Constructs in PLS-SEM. Australasian Marketing Journal. https://doi.org/10.1016/j.ausmj.2019.05.003.

Mallat, N., Rossi, M., Tuunainen, V.K. (2008). An Empirical Investigation of Mobile Ticketing Service Adoption in Public Transportation. Personal and Ubiquitous Computing, 12(1), 57-65. https://doi.org/10.1007/s00779-006-0126-z.

Mann, B.J.S., Sahni, S.K. (2012). Profiling Adopter Categories of Internet Banking in India: An Empirical Study. Vision, 16(4), 283-295. https://doi.org/10.1177/0972262912460187.

Maruping, L.M., Bala, H., Venkatesh, V., Brown, S.A. (2017). Going Beyond Intention: Integrating Behavioural Expectation into the Unified Theory of Acceptance and Use of Technology. Journal of the Association for Information Science and Technology, 68, 623-637. doi:10.1002/asi.23699.

Wang, M., Cho S., Denton, T. (2017). The Impact of Personalization and Compatibility with Past Experience on E-banking Usage. International Journal of Bank Marketing, 35(1), 45-55. https://doi.org/10.1108/IJBM-04-2015-0046.

Farah, M.F., Hasni, M.J.S., Abbas, A.K. (2018). Mobile Banking Adoption: Empirical Evidence from the Banking Sector in Pakistan. International Journal of Bank Marketing, https://doi.org/10.1108/IJBM-10-2017-0215.

Mehrad, D., Mohammadi, S. (2016). Word of Mouth Impact on the Adoption of Mobile Banking in Iran. Telematics and Informatics, (2016), doi: http://dx.doi.org/10.1016/j.tele.2016.08.009.

Harris,M., Cox, K.C., Musgrove, K.F., Ernstberger, K.W. (2016). Consumer Preferences for Banking Technologies by Age Groups. International Journal of Bank Marketing, 34(4), 587-602. https://doi.org/10.1108/IJBM-04-2015-0056.

Mohd Noor, Nor Azila, Aljanabi, A. (2016). Moderating Role of Absorptive Capacity between Entrepreneurial Orientation and Technological Innovation Capabilities. International Review of Management and Marketing, 6(4), 704-710.

Mohsin Butt, M., Aftab, M. (2013). Incorporating Attitude Towards Halal Banking in an Integrated Service Quality, Satisfaction, Trust and Loyalty Model in Online Islamic Banking Context. International Journal of Bank Marketing, 31(1), 6-23, https://doi.org/10.1108/02652321311292029

Passas, N. (2005a). Indicators of Hawala Operations and Criminal Abuse. Journal of Money Laundering Control, 8(22), 168-172. Retrieved from http://dx.doi.org/10.1108/13685200510621145.

Passas, N. (2005b). Law Enforcement Challenges in Hawala-related Investigations. Journal of Financial Crime, 12(2), 112-119. Retrieved from http://dx.doi.org/10.1108/13590790510624963.

Rahomee, A., Aljanabi, A., Mohd Noor, Nor Azila, Dileep, K.M., Othman Abdullah, Y. (2014). The Mediating Role of Absorptive Capacity in Its Effect on Organizational Support Factors and Technological Innovation. Information Management and Business Review, 6(1), 25-41, Feb 2014.

Acharya, R.N., Kagan, A., Lingam, S.R., (2008). Online Banking Applications and Community Bank Performance. 
International Journal of Bank Marketing, 26(6), 418-439, https://doi.org/10.1108/02652320810902442.

Glavee-Geo, R., Shaikh, A.A., Karjaluoto, H. (2017). Mobile Banking Services Adoption in Pakistan: are There Gender Differences?. International Journal of Bank Marketing, 35(7), 1090-1114, https://doi.org/10.1108/IJBM-09-2015 0142.

Riffai, Grant and Edgar. (2011), Big TAM in Oman: Exploring the promise of on-line banking, its adoption by customers and the challenges of banking in Oman, International Journal of Information Management 32 (2012) $239-250$. doi:10.1016/j.ijinfomgt.2011.11.007.

Rigdon, E.E., Ringle, C.M., Sarstedt, M. (2010). Structural Modeling of Heterogeneous Data with Partial Least Squares. In N.K. Malhotra (ed.), Review of Marketing Research (pp.255-296). Sharpe: Armonk. doi:10.1108/S15486435(2010)0000007011.

Saad Alaaraj, Zainal Abidin Mohamed, Ummi Salwa Ahmad Bustamam, (2018) „External growth strategies and organizational performance in emerging markets: The mediating role of interorganizational trust", Review of International Business and Strategy, Vol. 28 Issue: 2, pp.206-222, https://doi.org/10.1108/RIBS-09-2017-0079.

Alaarj, S., Abidin-Mohamed, Z., Bustamam, U. (2016). Mediating Role of Trust on the Effects of Knowledge Management Capabilities on Organizational Performance. Procedia - Social and Behavioural Sciences, 235(2016), 729-738, ISSN 1877-0428, https://doi.org/10.1016/j.sbspro.2016.11.074.

Yaseen, S.G., El Qirem, I.A. (2018). Intention to Use E-banking Services in the Jordanian Commercial Banks. International Journal of Bank Marketing, 36(3), 557-571, https://doi.org/10.1108/IJBM-05-2017-0082.

Sarstedt, M., Cheah, J.H. (2019). Partial Least Squares Structural Equation Modeling Using SmartPLS:a Software Review. Journal of Marketing Analytics. https://doi.org/10.1057/s41270-019-00058-3.

Schneider, F. (2010). Turnover of Organized Crime and Money Laundering: Some Preliminary Empirical Findings. Public Choice, 144(3), 473-486. https://doi.org/10.1007/s11127-010-9676-8.

Schramm, M., Taube, M. (2003). Evolution and Institutional Foundation of the Hawala Financial System. International Review of Financial Analysis, 12(4), 405-420. https://doi.org/10.1016/S1057-5219(03)00032-2.

Shanmugam, B. (2004). Hawala and Money Laundering: a Malaysian perspective. Journal of Money Laundering Control, 8(1), 37-47. https://doi.org/10.1108/13685200510621181.

Shih, Y.Y., Fang, K. (2004). The Use of a Decomposed Theory of Planned Behaviour to Study Internet Banking in Taiwan. Internet Research, 14(3), 213-223. DOI 10.1108/10662240410542643.

Shmueli, G., Ray, S., Velasquez Estrada, J.M., Chatla, S.B. (2016). The Elephant in the Room: Evaluating the Predictive Performance of PLS Models, Journal of Business Research, 69(10), 4552-4564. http://dx.doi.org/10.1016/j. jbusres.2016.03.049.

Sohail, Shanmugham (2002). E-banking and Customer Preferences in Malaysia: An empirical investigation. Information Sciences, 150(2003), 207-217. PII: S0 020 -0 255 (0 2 )00 378 -X.

Soudjin, M. (2015). Hawala and Money Laundering: Potential Use of Red Flags for Persons Offering Hawala Services. European Journal on Criminal Policy and Research, 21(2), 257-274. https://doi.org/10.1007/s10610-014-9238-6.

T.C. Edwin Cheng, David Y.C. Lam, Andy C.L. Yeung, Adoption of internet banking: An empirical study in Hong Kong, Decision Support Systems, Volume 42, Issue 3, 2006, Pages 1558-1572, https://doi.org/10.1016/j.dss.2006.01.002.

USAID, 2008. Kurdistan Region, Economic Development Assessment Final Report, RTI-International December 2008. This publication was produced for review by the United States Agency for International Development.

Venkatesh, V., Bala, H. (2007). Technology Acceptance Model 3 and a Research Agenda on Interventions. Decision Sciences, 39, 273-315. doi:10.1111/j.1540-5915.2008.00192.x.

Venkatesh, V., Morris, M.G., Davis, G.B., Davis F.D (2003). User Acceptance of Information Technology: Toward a Unified View. MIS Quarterly, 27(3), (Sep., 2003), 425-478.

Venkatesh, V., James, Y.L. Thong, Xin Xu. (2012). Consumer Acceptance and Use of Information Technology: Extending the Unified Theory of Acceptance and Use of Technology. MIS Quarterly 36(2012), 157-178. DOI:10.2307/41410412

Veul, R.M., van Charldorp, T.C., Soudijn, M.R.J. (2017). Online Public Response to Dutch News About Money Laundering. European Journal on Criminal Policy and Research, 23(2), 227-244. https://doi.org/10.1007/s10610-016-9315-0.

Chauhan, V., Yadav, R., Choudhary, V. (2019). Analyzing the Impact of Consumer Innovativeness and Perceived Risk 
in Internet Banking Adoption: A Study of Indian consumers. International Journal of Bank Marketing, 37(1), 323-339, https://doi.org/10.1108/IJBM-02-2018-0028.

Chaouali, W., El Hedhli, K. (2019). Toward a Contagion-Based Model of Mobile Banking Adoption. International Journal of Bank Marketing, 37(1), 69-96, https://doi.org/10.1108/IJBM-05-2017-0096.

Warsame, M.H., Ireri, E.M. (2018). Moderation Effect on Mobile Microfinance Services in Kenya: An Extended UTAUT Model. Journal of Behavioural and Experimental Finance (2018). https://doi.org/10.1016/j.jbef.2018.01.008.

Zhang, Y., Weng, Q., Zhu, N. (2018). The Relationships Between Electronic Banking Adoption And its Antecedents: A meta-analytic Study of the Role of National Culture. International Journal of Information Management, Volume 40, 2018, 76-87, https://doi.org/10.1016/j.ijinfomgt.2018.01.015. 